\title{
Metafísica da soberania e da representação política
}

\author{
Metaphysics of sovereignty and political representation
}

Diogo Bogéa

UERJ

\begin{abstract}
Resumo: Investigação acerca das bases metafísicas dos conceitos de soberania e de representação política. Num franco diálogo com teorias psicanalíticas, partimos de uma caracterização do "poder absoluto" (evocado pelo conceito de soberania) como fantasia pullsional. Em seguida, apresentamos a problemática da soberania recorrendo aos principais teóricos da filosofia política modema a fim de demonstrar que a soberania, compreendida como "poder absoluto", desdobra-se necessariamente em níveis de "representação". Recorremos à noção derridiana de "suplemento" para descrever a lógica da "representação" do poder absoluto por instâncias suplementares que, a um só tempo prometem e adiam sua presença impossível.
\end{abstract}

Palavras chave: metafísica; soberania; representação; fantasia; pulsão

\begin{abstract}
Research on the metaphysical foundations of the concepts of sovereignty and political representation. In a frank dialogue with psychoanalytic theories, we begin with a characterization of "absolute power" (present in the notion of sovereignty) as a drive fantasy. Next, we present the problematic of sovereignty by recourse to the main theorists of modern political philosophy in order to demonstrate that sovereignty, understood as "absolute power", necessarily unfolds at levels of "representation". We used the Derridean notion of "supplement" to describe the logic of "representation" of the absolute power by supplementary instances that, at the same time, promise and postpone its impossible presence.
\end{abstract}

Keywords: metaphysics; sovereignty; representation; fantasy; drive

\section{Considerações iniciais}

No prefácio de O Espírito das leis, Montesquieu afirma: "Examinei primeiro os homens, e achei que nesta infinita diversidade de leis e de costumes eles não eram conduzidos somente por suas fantasias"1. Montesquieu é um homem do século XVIII e, como tal, compartilha com sua época a confiança no "primado absoluto da razão"2, que fazia dos pensadores

batallhadores, divulgadores, realizadores de um programa centrado na crítica racional do existente, em nome de princípios que apontavam para a possibilidade de libertar o homem do erro e do preconceito, e desobstruir o caminho para uma nova sociedade digna de uma humanidade reconciliada consigo mesma. ${ }^{3}$

A frase extraída do prefácio escrito por Montesquieu anuncia também o projeto - nada estranho ao espírito do seu tempo - de fazer uma "ciência" da política, de

\footnotetext{
${ }^{1}$ MONTESQUIEU. O Espírito das Leis. São Paulo: Martins Fontes, 1996, p. 5

${ }^{2}$ FALCON, Francisco. Iluminismo. São Paulo: Atica, 1994, p. 42

${ }^{3}$ Ibidem, p. 43
} 
construir um saber político, portanto, livre de "fantasias", superstições e dogmas religiosos. É o que se deixa ver na descrição precisa de Althusser:

A necessidade que governa a história, para começar a ser científica, deve deixar de beber a sua razão em qualquer ordem que transcenda a história. É, portanto, necessário varrer do caminho da ciência pretensões de uma teologia ou de uma moral que pretenderiam ditar-lhes leis. (...) Não é à teologia que cabe enunciar a verdade dos factos da política. (...) introduzir a teologia em história, é confundir as ordens e misturar as ciências. ${ }^{4}$

No entanto, para nós que atravessamos a "era dos extremos" totalitarismos de esquerda e de direita; duas guerras mundiais; extermínios em massa; armas químicas, biológicas e nucleares; ditaduras populistas, ditaduras militares, ditaduras do capital; para nós que vivemos no século XXI sob a sombra crescente do recrudescimento dos fundamentalismos religiosos (cristãos e islâmicos); sob a sombra dos "novos salvadores da pátria" que vencem eleições com frases feitas, informações falsas ("pós-verdadeiras") e promessas vazias de grandeza; sob a sombra de uma crescente onda de ódio, preconceito e intolerância cuja violência já começa a "transbordar" das redes sociais para as ruas; enfim, talvez para nós, em se tratando de política, não haja alternativa senão considerar - e muito seriamente - o poder das fantasias, das superstições e dos dogmas religiosos nas configurações políticas. O poder das fantasias de poder absoluto - fantasias de lucro, de consumo, de status, fantasias narcísicas, fantasias religiosas messiânicas de "santidade", "heroísmo", "sacrifício" e "salvação".

A consideração do papel ativo que as fantasias desempenham na vida psíquica e, portanto, na vida cotidiana e em todas as atividades humanas é uma das grandes contribuições da psicanálise para o pensamento ocidental. O psicanalista brasileiro MD Magno ressalta o quanto a descoberta do caráter intrinsecamente alucinatório do aparellho psíquico é fundamental para o nascimento da psicanálise:

O conceito de alucinação é fundamental no nascimento da psicanálise. A grande sacada de Freud foi perceber que o bebê alucina e que alucinamos as coisas. Alucinamos sempre, e não só de vez em quando. Ele adscreveu a produção imagética do sonho à pura alucinação: a repetição da alucinação que ele descobriu é pelo sonho. Por isso, o sonho é tão vívido. ${ }^{6}$

Em geral, a epistemologia ocidental situa a alucinação, o delírio, o sonho, a fantasia e mesmo a imaginação, para utilizar uma expressão de Ricoeur, no "extremo inferior da escala dos modos de conhecimento" ". A fantasia é sempre aquilo que deve ser corrigido, eliminado, superado para que possamos, enfim, livres dos erros, enganos e meras aparências a ela associadas, ajustar o intelecto e a razão à realidade.

Freud vem nos mostrar que um aparelho psíquico regido pelo princípio do prazer é também intrinsecamente alucinatório.

O programa de tomar-se feliz, que o princípio do prazer nos impõe não pode ser realizado; contudo, não devemos - na verdade, não podemos - abandonar nossos esforços de aproximá-lo da consecução, de uma maneira ou de outra. Caminhos muito diferentes podem ser tomados nessa direção, e podemos conceder prioridades quer ao aspecto positivo do objetivo, obter prazer, quer ao negativo, evitair o desprazer. Nenhum desses caminhos nos leva a tuido o que desejamos. ${ }^{8}$

\footnotetext{
${ }^{4}$ ALTHUSSER, Louis. Montesquieu, a Política e a História. Lisboa: Editorial Presença, 1977, p. 24

${ }^{5}$ HOBSBAWM, Eric. A Era dos Extremos. São Paulo: Companhia das Letras, 1995

${ }^{6}$ MAGNO, MD. Clavis Universalis. Rio de Janeiro: Novamente, 2007, p. 130

${ }^{7}$ RICOEUR, Paul. De la memoire, de l'histoire, de l'oubli. Paris: Seuil, 2000, p. 5

${ }^{8}$ FREUD, Sigmund, O mal-estar na civilização. Rio de Janeiro: Imago, 1974, p. 102
} 
O objetivo do princípio de prazer - o gozo do prazer absoluto, ou da absoluta evitação do desprazer - é absolutamente impossível. No entanto, não deixamos jamais de desejá-lo e buscá-lo. Mas o desejo - e com o desejo a busca - de um "além" de todo possível, por não se tratar da busca de "algo" realmente existente em qualquer tempo ou lugar, não pode não ser regida pela fantasia.

Em Formulações sobre os dois princípios do funcionamento mental, de 2011 , Freud já indica a indissociabilidade entre princípio de prazer e fantasia, afirmando que esta última resta de certa forma imune ao "teste de realidade": a atividade do "fantasiar, que começa já nas brincadeiras infantis, e posteriormente, conservada como devaneio, abandona a dependência de objetos reais"10. Nesse mesmo texto, Freud trata da "satisfação alucinatória" dos bebês, cujo desejo vai progressivamente - pelas frustrações e testes de realidade - se adaptando, de certa forma, à realidade. No entanto, em $O$ mal estar na civilizizção o poder da alucinação na vida psíquica é radicalizado, pois Freud aborda diversos projetos de vida que correspondem a diversas maneiras de buscar a satisfação do princípio de prazer, e inclui entre elas aquela que "considera a realidade como a única inimiga e a fonte de todo o sofrimento, com a qual é impossível viver, de maneira que, se quisermos ser de algum modo felizes, temos de romper todas as relações com ela"11

A forma de manifestação mais extremada desta via é "tentar recriar o mundo, em seu lugar construir um outro mundo, no qual os seus aspectos mais insuportáveis sejam eliminados e substituídos por outros mais adequados a nossos próprios desejos"12. Aquele que procede desta forma, se "não encontra ninguém para ajudá-lo a tornar real o seu delírio", "torna-se um louco"13. Mas, vejamos o seguinte:

Afirma-se, contudo, que cada uim de nós se comporta, sob determinado aspecto, como um paranoico, corrige algum aspecto do mundo que The é insuportável pela elaboração de uim desejo e introduz esse delírio na realidade. Concede-se especial importância ao caso em que a tentativa de obter uma certeza de felicidade e uma proteção contra o sofrimento através de uim remodelamento delirante da realidade, é efetuada por um considerável número de pessoas. As religiões da humanidade devem ser classificadas entre os delííos de massa desse tipo. $\hat{\mathrm{E}}$ desnecessário dizer que todo aquele que partilha um delírio jamais o reconhece como tal. ${ }^{14}$

Mas, isso nos permite colocar a questão: o que é a realidade? Haveria uma realidade pura, independente dos desejos e fantasias? Não estará tudo aquilo que chamamos de "realidade" sempre já irremediavelmente contaminado, misturado, imbricado com "delírios" e "remodelamentos delirantes" mais ou menos compartilhados e mais ou menos cristalizados?

É a partir dessa postulação freudiana do primado do princípio de prazer e de sua estrutura necessariamente "fantasista", que o psicanalista MD Magno, via Lacan, elabora seu conceito de Pulsão - o "conceito fundamental da psicanálise" - como "haver-desejode-não-hhaver": desejo de um gozo absoluto, impossível, que não-há e cujo atingimento coincidiria com a morte absoluta, o não-mais-haver da pulsão enquanto pulsão. A pulsão é, portanto, necessariamente, uma espécie de impulso alucinatório, que não cessa de projetar como possível uma satisfação absoluta absolutamente impossível:

fora do i̊mpulso alucinatório, que costumamos chamar de Pulsão, não é possível pensar uma economia psíquica ou qualquer outra. Começa-se daí e isto já é o bastante para entender nossa loucura, nosso corre-corre atrás do quêe? De uma

\footnotetext{
${ }^{9}$ FREUD, S., Formulação sobre os dois princípios do funcionamento mental Rio de Janeiro: Imago, 1975, p. 281

${ }^{10}$ Ibidem, pp. 281-282

${ }^{11}$ FREUD, S., O Mal-estar na civilização, Rio de Janeiro: Imago, 1974, p. 100

${ }^{12}$ Ibidem, p. 100

${ }^{13}$ Ibidem, p. 100

${ }_{14}$ Ibidem, p. 100
} 
alucinação, que, no entanto, não vai sossegar só porque queremos. A alucinação está lá como (e na) estrutura: a estrutura alucina, empurra, empuxa, impulsiona nesse sentido. ${ }^{15}$

Impulso alucinatório que não cessa de projetar como possível um poder absoluto de realização. Desejar é desejar o impossível. Impossível é o que não pode se realizar sob nenhuma combinação possível de circunstâncias, é o que simplesmente não-há. Diante desse limite absoluto, dessa impotência incontornável em face da impossibilidade de realização absoluta, a estrutura psíquica está sempre referida a projeções alucinatórias de algum poder absoluto de realização. No lugar do impossível desejado, inscrevem-se fantasias de poder absoluto - de gozo absoluto, paz perpétua, saída definitiva, resolução final, vitória inapelável, decisão soberana, controle absoluto, etc. - que co-movem a estrutura psíquica.

Portanto, fantasias de poder absoluto permeiam a vida cotidiana, desde a infância:

Do ponto de vista de sua experiência, enquanto crianças, as pessoas acreditaram encontrar nos adultos, parentais ou não, essa instância decisória e aparentemente precisa, que, mais tarde, virão distribuir por funções sociais, como juízes, mestres, médicos, padres, policiais... 16.

Fantasias de poder absoluto constituem também o fundo alucinatório-pulsional de todas as religiões. Noções religiosas fundamentais como "Deus" e "eternidade" revelam a fantasia - e com a fantasia, o desejo - de um poder absoluto de existência autossuficiente - o poder de existir em si e por si mesmo, de maneira completamente independente e livre de qualquer determinação ou condicionamento -, bem como de um poder absoluto de criação, sustentação, regência, governo, proteção, julgamento, punição, sabedoria - o poder de tudo ver e tudo saber - etc.

o Deus judaico-cristão, ao acumular todos esses poderes que, nas religióes politeístas são, em geral, repartidos e divididos entre as divindades ${ }^{17}$, isto é, ao acumular os poderes de existir em si e por si mesmo de maneira completamente independente e autossuficiente; o poder de criar o mundo, os humanos e todas as coisas a partir do nada; o poder de sustentar e governar absolutamente o devir do mundo; o poder de tudo ver e tudo saber - sobre tudo, em todos os tempos e lugares; o poder absoluto de proteger, mas também de julgar e condenar ou absolver; o poder de estar em tudo, em todos os entes, em todos os lugares a todo momento; constitui uma das formas mais extremadas e mais bem acabadas da fantasia desejante de poder absoluto.

A grande questão da Filosofia Política moderna é a questão da soberania, isto é, a questão sobre quem ou o que detém o poder absoluto. Quem pode exercer o poder absoluto de maneira legítima e o que legitima, afinal, o exercício do poder absoluto? A partir de nossas considerações iniciais, pretendemos investigar, contrariando Montesquieu, o papel das fantasias - especialmente das fantasias de poder absoluto nas configurações sociopolíticas. Por outro lado, contrariando Althusser, investigar em que medida Carl Schmitt tem razão ao afirmar que "Todos os conceitos significativos da doutrina do Estado moderna são conceitos teológicos secularizados ${ }^{p 18}$, ou seja, trata-se de pensar em que medida não será mesmo impossível fazer uma "ciência" pura da política, livre de qualquer influência ou determinação religiosa.

Faremos uma breve apresentação dos principais teóricos da Filosofia Política contemporânea a fim de demonstrar que o conceito de "soberania" constitui uma

\footnotetext{
${ }^{15}$ MAGNO, M.D., Economia Fundamental Rio de Janeiro: Novamente, 2012, p. 21

${ }^{16}$ MAGNO, M.D. A rebeliào dos anjos. Rio de Janeiro: Novamente, 2009, p. 125

17 “Nos sistemas politeístas, por exemplo, nem mesmo um deus, por mais poderoso que seja, pode ser soberano; somente quando se supõe um deus único a soberania e a liberdade podem ser idênticas" (ARENDT, Hannah, $A$ Condição Humana Rio de Janeiro: Forense Universitária, 2010, p. 292)

${ }^{18}$ SCHMTTT, Carl. Politische Theologie. Berlim: Duncker \& Humblot, 1996, p. 43 
fantasia pulsional de "poder absoluto". Como o "poder absoluto" nunca pode se exercer enquanto tal, desdobra-se necessariamente numa intrincada rede de níveis de "representação" política, cujos avatares mais recorrentes são "Deus", o "Estado", o "Rei", a "Lei" e o "povo". Recorreremos à noção derridiana de "suplemento" para demonstrar que a relação entre "soberania" e "representação política", isto é, a relação entre o "poder absoluto" e seus "representantes" implica uma lógica da "suplementaridade", ou seja, não podendo se exercer enquanto tal, o poder absoluto se faz "representar" por suplementos que a um só tempo prometem e adiam sua presença. Nas considerações finais, a partir das chaves de leitura construídas ao longo do artigo, procuramos tecer considerações acerca de questões sociopolíticas contemporâneas.

\section{Metafísica da soberania}

Não seria exagero afirmar que a questão central da Filosofia Política moderna é a questão da soberania: a questão sobre quem ou o que detém o poder absoluto e o que faz desse poder um poder legítimo. Nas palavras de Foucault: "A teoria do direito, da Idade Média em diante, tem essencialmente o papel de fixar a legitimidade do poder, isto é, o problema maior em torno do qual se organiza toda a teoria do direito é o da soberania". 19 Foucault nos chama a atenção para o fato de que os discursos modernos acerca da soberania não devem ser tratados como elaborações puramente teóricas do intelecto e da razão. Nesse sentido, as modernas teorias da soberania não se reduzem a um saber teórico-racional sobre a política e o exercício do poder. Foucault nos mostra que tanto o direito quanto as filosofias políticas que o acompanham, legitimam, expressam, veiculam relações de poder e de dominação. O direito e as filosofias políticas que o acompanhlham são a um só tempo constituídos por e constituintes de uma rede de relações muito concretas de poder e dominação. Tomaremos como ponto de partida a advertência inicial de Foucault, mas para desenvolvê-la num sentido um pouco diferente: será nosso interesse investigar em que medida as teorias filosófico-jurídicas da soberania expressam, exprimem, manifestam, revelam fantasias pulsionais de poder absoluto.

A questão da soberania foi muito bem apresentada pelo psicanalista MD Magno da seguinte maneira:

como dar conta da soberania? O que é a soberania? O que é o soberano? Soberano é o poder máximo. Aquilo ou quem detém o poder máximo de decisão. (...) Mas como identificar o tal soberano? Quem é o soberano? As teorias jurídicas e mesmo as teorias políticas ficam em palpos de aranha para poder decidir isto. Se encararmos do ponto de vista jurídico, o soberano é aquele que, por um ato de decisão, determina a lei. Mas se o soberano é uim conceito juirídico, ele é designado pela lei. Então, como sair desse impasse, desse círculo vicioso de o soberano determinar a lei e de a lei determinar o soberano? ${ }^{20}$

Questão longamente discutida por Derrida em Força de leĩ:

Não há direito que não implique nele mesmo, a priori, na estrutura analítica de seu conceito, a possibilidade de ser "enforced", aplicado pela força. (...) Existem, certamente, leis não aplicadas, mas não há lei sem aplicabilidade, e não há aplicabilidade ou "enforceability" da lei sem força, quer essa força seja direta ou não, física ou simbólica, exterior ou interior, brutal ou sutilmente discuirsiva - ou hermenêutica -, coercitiva ou reguladora etc.

Como distinguir entre essa força da lei, essa "força de lei" (...) e por outro lado a violência que julgamos sempre injusta? Que differença existe entre, por um lado, a força que poder ser justa, em todo caso julgada legítima (...) e, por outro lado, a

\footnotetext{
${ }^{19}$ FOUCAULT, Michel. Soberania e disciplina. In: Microfísica do Poder. Rio de Janeiro: Paz e Terra, 2014, p. 281

${ }^{20}$ MAGNO, MD. Revirão. Rio de Janeiro: Novamente, 2003, p. 408 
violência que julgamos injusta? O que é uma força justa ou uima força não violenta?21

O poder soberano, onde quer que se o identifique - no monarca, num grupo de notáveis, no Estado, no povo, na vontade geral, nas próprias leis - é supostamente um poder absoluto, um poder incontestável, um poder além de todo poder relativo ou. condicionado. O poder soberano faz a lei e garante a legitimidade da lei, bem como sua justa aplicabilidade. Mas o que garante a legitimidade do poder soberano? O que garante a legitimidade de um poder anterior - logicamente anterior e hierarquicamente superior - à própria lei, e, portanto, à própria noção de legitimidade?

O próprio surgimento da justiça e do direito, o momento instituidor, fundador e justificante do direito, implica uma força performativa, isto é, sempre uma força interpretadora e um apelo à crença desta vez, não no sentido de que o direito estaria a serviço da força, instrumento dócill, servil e portanto exterior do poder dominante, mas no sentido de que ele manteria, com aquilo que chamamos de força, poder ou violência, uma relação mais interna e mais complexa. A justiça no sentido do direito (right or law) - não estaria simplesmente a serviço de uma força ou de um poder sociall, por exemplo econômico, político, ideológico, que existiria fora dela ou antes dela, e ao qual ela deveria se submeter ou se ajustar, segundo a utilidade. (...) Ora, a operação de fundar, inaugurar, justificar o direito, fazer a lei, consistiria num golpe de força, numa violência performativa e portanto interpretativa que, nela mesma não é justa nem injusta, e que nenhuma justiça, nenhum direito prévio e anteriomente fundador, nenhuma fuindação preexistente, por definição, poderia nem garantir nem contradizer ou invalidar. Nenhum discurso justificador pode, nem deve, assegurar o papel de metalinguagem com relação à performatividade da linguagem instituinte ou à sua interpretação dominante. ${ }^{22}$

É esse caráter necessariamente "infundado" do poder soberano, que Derrida chama de "fundamento místico da autoridade". O poder soberano, enquanto poder autofundado e auto-fundamentado, fundado e fundamentado apenas por si mesmo, paira sempre necessariamente sobre um fundo sem-fundo. $\mathbb{E}$ um poder que se impõe como que vindo "do além", isto é, um poder que se põe sempre "para além" de toda possibilidade de racionalização, justificação e legitimação e que, portanto, exige - pela força - que nele se acredite.

Mas uma tal concepção do poder é uma concepção essencialmente religiosa. É o que nos mostra Eric Voegelin em seu belo Religiōes Politicas:

Uma definição escolar de Estado, que até hoje ninguém suspeitou de ter pretensões religiosas, diz que o Estado constitui uma união associativa de homens sedentários, dotada de um poder soberano originário. Muitos dos elementos desta definição dizem manifestamente respeito a factos da experiência concreta: homens, associados, sedentários, sobre um território. Contudo, um outro elemento, o poder soberano originário, desperta as dúvidas. "Originário" não pode significar senão o facto de o poder não ter outra fonte senão a do próprio Estado, que não pode derivar de nenhuma outra parte, que é absoluto. Üm olhar sobre a realidade revela que tal afirmação é falsa. Üm poder absoluto, originário, é um poder acima de todos os poderes; não há outro poder ao seu lado, nem acima dele e, abaixo dele, somente os poderes que lhe são devotos. Ora, apesar disso, o poder do. soberano tem barreiras no seu interior, porque existem coisas que nenhum soberano pode fazer sem ser derrubado, e barreiras para o exterior, face aos outros poderes soberanos. (...)

Tal pluralismo de poderes leva-ños a repor a questão da sua proveniência. $O$ carácter originário do poder, a sua supremacia, tem um sentido superlativo, ou seja, a afirmação de que o poder em questão é o mais alto. (...)

${ }^{21}$ DERRIDA, Jacques. Força de Lei São Paulo: Martins Fontes, 2010, pp. 8-9

${ }^{22}$ Ibidem, p. 24 
A supremacia afirma-se aí simplesmente com o sentido de uma constatação empírica, que aspira à verdade. ${ }^{23}$

É justamente nesse ponto levantado por Voegelin que gostaríamos de insistir: o "poder absoluto" não pode ter uma justificativa racional, pois uma vez que se apresenta como absoluto, o faz num ato de força que exige crença, isto é, apresentando-se como originário, não pode remeter a nenhum fundamento mais elementar que o justifique. Mas, também não pode ser constatado empiricamente, pois um poder efetivamente atuante, nunca é absoluto. Poder não é "algo" que "alguém" - o Rei, o povo ou a classe dominante - detém. Poder implica necessariamente relação. Relação de forças que, atuando umas sobre as outras, atravessam-se e se constituem mutuamente, mas também limitam, condicionam e determinam mutuamente a extensão e a intensidade dos seus poderes de atuação. Retomando Nietzsche, Foucault expressa com muita precisão o caráter necessariamente relacional e agonístico do poder:

Não tomar o poder como um fenômeno de dominação maciço e homogêneo de uim indivíduo sobre os outros, de uim grupo sobre os outros, de uma classe sobre as outras; mas ter bem presente que o poder - desde que não seja considerado de muito longe - não é algo que se possa dividir entre aqueles que o possuem e o detêm exclusivamente e aqueles que não o possuem e lhe são submetidos. $O$ poder deve ser analisado como algo que circula, ou mellhor, como algo que só funciona em cadeia. Nunca está localizado aqui ou ali, nunca está nas mãos de alguins, nuinca é apropriado como uma riqueza ou um bem. O poder funciona e se exerce em rede. Nas suas malhas, os indivíduos não só circulam, mas estão sempre em posição de exercer esse poder e de sofirer sua ação; nuinca são o alvo inerte ou consentido do poder, são sempre centros de transmissão. ${ }^{24}$

Ora, mas "poder soberano" diz justamente "poder absoluto": um poder acima de toda e qualquer relação, determinação ou condicionamento. Mas se o poder, por sua própria natureza, só pode ser relacional - e, portanto, nunca "absoluto" - temos de admitir, seguindo nossas considerações iniciais, que toda suposição de "poder absoluto", inclusive no conceito de "soberania", expressa uma fantasia pulsional de poder absoluto, isto é, projeta como possível um poder absoluto de realização que é, por definição, absolutamente impossível.

Mas se o poder absoluto é absolutamente impossível, se o poder absoluto é o que não há nem pode haver sob qualquer combinação possível de circunstâncias, isso significa dizer que toda a metafísica política da soberania traz necessariamente inscrita em sua própria estrutura, a noção de representação. O poder absoluto, sendo absolutamente impossível, nunca é algo presente em si e por si mesmo, nunca se apresenta enquanto tal. Portanto, toda suposição de poder absoluto é a projeção da fantasia pulsional de poder absoluto numa instância que se apresenta como seu representante, uma instância que se dá em seu lugar. Assim, o Estado soberano, porque não pode exercer o poder absoluto enquanto tal, tem de se fazer representar pelo Rei que por sua vez é o representante do poder absoluto de Deus - ou pela lei - que por sua vez é a representante da "vontade geral" da nação ou do poder absoluto da razão - ou. pelo povo - que por sua vez tem que se fazer representar por mandatários ou delegados eleitos.

A metafísica política da soberania gera uma dinâmica da suplementaridade, para usar uma formulação de Derrida: os suplementos não são apenas algo que se acrescenta a "algo" realmente presente, eles se encarregam de substituir, representar a presença de um "poder absoluto" que não está lá. Ao mesmo tempo em que eles reafirmam a promessa de um "poder absoluto" realmente presente ao qual parecem se referir,

${ }^{23}$ VOEGELIN, Eric. As religiões políticas. Lisboa: Vega, 2002, p. 25

${ }^{24}$ FOUCAULT, Michel. Soberania e disciplina. In: Microfísica do Poder. Rio de Janeiro: Paz e Terra, 2014, p. 285 
denunciam sua irremediável ausência, na medida em que sempre se dão no lugar dele, como substitutos de um "poder soberano" efetivamente presente que nunca comparece.

O suiplemento supre. Ele não se acrescenta senão para substituiir. Intervém ou se insinua em Iugar de, se ele colma, é como se cumula um vazio. Se ele representa e faz imagem, é pela falta anterior de uma presença. Suplente e vicário, o suplemento é um adjunto, uma instância subalterna que substitui. Enquanto suibstituto, não se acrescenta simplesmente à positividade de uima presenç, não produz nenhum relevo, seu lugar é assinalado na estrutura pela marca de um vazio. Em alguima parte, alguma coisa não pode-se preencher de si mesma, não pode efetivar-se a não ser deixando-se colmar por signo e procuração. ${ }^{25}$

O jogo dos suplementos funciona sempre na suposição de referência a uma instância mais originária, um fundamento real, neste caso, um "poder soberano" presente ao qual os suplementos que lhe são próprios vêm se acrescentar. Mas, se o "poder absoluto" é sempre já uma fantasia pulsional, na origem do suplemento, antes do suplemento, não há um "poder absoluto" presente, mas já um suplemento:

O suplemento vem no lugar de um desfalecimento, de um não-significado ou de um não-representado, de uma não-presença. Nã̃o há nenhum presente antes dele, por isso só é precedido por si mesmo, isto é, por um outro suplemento. O suplemento é sempre o suplemento de um outro suplemento. Deseja-se remontar do suplemento à fonte: deve-se reconhecer que há suplemento na fonte.26

O poder soberano, fazendo referência a seus suplementos - Deus, o Rei, a lei, o povo - na tentativa de se apresentar, trai a própria presença que anuncia ao mesmo tempo em que denuncia sua própria não-presença.

Ciclo indefinido: a fonte - representada - da representação, a origem da imagem pode por sua vez representar seus representantes, substituir seus suibstituitos, suprir seus suplementos. Dobrada, retornando a si mesma, representando-se a si mesma, soberana, a presença não é então - e ainda - mais quie um suplemento desuplemento. ${ }^{27}$

\section{Soberania e representação política}

Ainda no contexto do Renascimento, Maquiavel lançou as bases da Filosofia Política Moderna. A política como "propriedade natural" do humano ou como "ordem imposta" ao mundo a partir do além, passa a ser compreendida como atividade propriamente humana, atividade "constitutiva da existência coletiva":

Quaisquer que sejam as continuidades (ou filliações) idleais entre a Antiguidade e a Idade Média, por um lado, e os Tempos Modernos, por outro, o "secretário florentino" introduziu uma ruptura decisiva; contra as teorias da sociabillidade natural, contra os ensinamentos da Revelaça e os da teologia, ele afirma porque constata - que, no que se refere às atividades coletivas, o que é é o Estado. Foi ele quem deu a esse último termo sua significação de poder central soberano legiferante e capaz de decidir, sem compartilhar esse poder' com ninguém, sobre as questões tanto exteriores quanto internas de uma coletividade; ou seja, de poder que realiza a laicização da plenitudo potestatis. ${ }^{28}$

A teoria da plenitudo potestatis remete à teoria das duas espadas:

${ }^{25}$ DERRIDA, Jacques. Gramatologia, São Paulo: Perspectiva, 2004, p. 178

${ }^{26}$ Ibidem, p. 371

${ }^{27}$ Ibidem, p. 364

${ }^{28}$ CHÂTELET, Francois; DUGAMEL, Olivier, História das Ideias Politicas, Rio de Janeiro: Zahar, 1990, p. 38 
que visa a normalizar, no Ocidente, depois da separação dos dois iimpérios, que se torna efetiva no século $\mathrm{V}$, as relações entre a ordem temporal própria dos "reinos" (e, em particular, o que está chamado a suceder o Império Romano) e a ordem espiritual sobre a qual reina o bispo de Roma, o Papa. Formalmente, tal como foi exposta pelos Papas Gelásio e Gregónio o Grande (540-604), a teoria é clara: somente Deus detém a plenitudo potestas, a potência suprema; todavia, no mundo cá de baixo, feito de espiritualidade e de materialidade, a onipotência delega a dois poderes distintos o cuidado de fazer a ordem divina triunfar: ao Pontífice, a auctoritas, a mais alta dignidade; ao Rei, a potestas temporal. ${ }^{29}$

Nesse sentido, como afirmou Eric Voegelin, na concepção do Estado como "soberano", "a cabeça divina é abatida e no lugar do deus transcendente, o Estado impõese no mundo como a condição última e a origem do seu próprio ser"30 . "poder absoluto" de $\mathbb{D}$ eus se faz representar na Terra pelo "poder absoluto" do Estado. Mas como o "poder absoluto" do Estado não pode se fazer valer por si mesmo, é preciso que o Estado se faça representar pelo "príncipe", agora chamado "soberano".

Jean Bodin é considerado o grande teórico do Estado soberano. Bodin toma como "dado de fato" a existência de "um poder público unificado e unificante" essencialmente caracterizado pela "potência soberana"31.

O termo "soberania" - majestas ou potestas - deve ser tomado em sua acepção mais rigorosa: a potência soberana do Estado é absoluta: ela comanda e não recebe nenhuim comando; não depende de nada nem de ninguém: nem de Deus, nem da Natureza, nem do Povo; não exige nenhum fundamento: é autosuificiente; é indivisível, no sentido de que é por essência una e, se for delegada, está integralmente em cada delegação; é perpétua: não poderia sofrer as vicissitudes do tempo e, por essa razão, é transcendente. Em suma, ela é: tal como, segundo os teólogos, Deus é. O Estado é a sede da soberana potência, o ponto focal da ordem pública. ${ }^{32}$

O Estado se dá como encarnação do poder absoluto de Deus: um poder autofundado, autossuficiente, indivisível e perpétuo. Mas, mais uma vez, como um tal "poder absoluto" nunca existe em si e por si mesmo, pois é sempre fruto de uma fantasia pulsional de poder absoluto, o Estado "soberano" tem de se fazer representar pelas "Leis":

O Estado é a sede da soberana potência, o ponto focal da ordem pública. Essa ordem é definida pelas Leis: essas determinam, segundo a necessidade, as normas da existência social em seu aspecto público; o Estado é senhor de "dá-las e de revogá-las". Do mesmo modo, pertence às suas prerrogativas absolutas declarar a paz e a guerra, dirigir a administração, juilgar em última instância e conceder a graça, cunhar moeda e arrecadar impostos. ${ }^{33}$

As Leis representam o poder do Estado soberano que é "senhor de dá-las e revogá-las". Mas como "O Estado" por si só constitui já uma abstração, uma projeção ideal de poder absoluto, é preciso que a "potência soberana" do Estado se faça representar de alguma maneira: "A potência soberana pode ser o Povo, uma parte do Povo ou um Indivíduo", configurando repúblicas "democráticas, aristocráticas e monárquicas"34. "O Povo", "uma parte do povo" ou "um indivíduo" se dão como representantes do poder absoluto do Estado e, por sua vez, se fazem representar pelas Leis que instituem. Afinal, "para se exercer, a potência tem de se encarnar nas

\footnotetext{
${ }^{29}$ Ibidem, p. 32

${ }^{30}$ VOEGELIN, Eric. As Religióes Polliticas Lisboa: Vega, 2002, p. 25

31 CHÂTELET, François; DUGAMEL, Olivier. História das Ideias Polf́ticas. Rio de Janeiro: Zahar, 1990, p. 46

32 Ibidem, p. 47

33 Ibidem, p. 47

${ }^{34}$ Ibidem, $\rho .47$
} 
instituições empíricas que têm a missão de governar" ${ }^{\prime 35}$. Esse ter de se encarnar empiricamente torna o poder absoluto absolutamente impotente para se exercer por si mesmo, faz do poder absoluto algo que nunca se apresenta enquanto tal, mas sempre se faz representar por alguma instância "suplementar" que se dá em seu lugar.

A mesma dinâmica da suplementaridade se verifica nos teóricos do "contrato social". Em Hobbes o "estado de natureza" é marcado pela "guerra de todos contra todos". Os humanos são potências desejantes que, na falta de um poder superior que limite sua liberdade, violentam-se mutuamente, agridem-se, avançam sobre as posses alheias. Esta situação, que é de guerra perpétua regida por desejos egoísticos de poder, configura também uma situlação de medo e insegurança perpétuos. Faz-se necessário então que os indivíduos, abrindo mão da liberdade de exercer seu poder, instituam um poder maior, absoluto, soberano, capaz de manter a ordem e a paz:

Dado que o estado de natureza é insuportável, dado que o desejo de poder e o desejo de viver (e de viver em paz) se contradizem, então surge a capacidade deliberativa própria ao homem que comanda de construir uma instância suiperior, cujo fim é impor uma ordem que elimine a violência natural, que substitua a guerra de todos contra todos pela paz de todos com todos.. Ao grande mal, deve-se responder com o grande remédio: para pôr fiim à violência nascida do exercício de potências por definição ilimitadas, só pode ser eficaz uma potência que não conheça limites. Isso significa, em palavras claras, que a instauração da sociedade política - commonwealth civitas -, do Estado, pressuipõe que os cidadãos, de comuim acordo, despojem-se integralimente de sua potência individual e a transfiram para a autoridade pública. A soberania una e indivisível do Estado é ilimitada: o contrato que a estabelece não a sujeita a nenhuma obrigação, salvo a de assegurar a tranquilidade e o bem-estar dos contratantes. Temos aqui o deus mortal, o Leviatã, esse monstro da lenda fenícia que é evocado pela Bíblia para dar a imagem de uma força corporal à qual nada resiste. Dessa feita, a laicização completa da plenitudo potestas dos teólogos realiza-se na própria noção do Estado ${ }^{36}$

Curiosamente, no capítulo anterior ao famoso capítulo XVII, que descreve o pacto instituinte do "Deus mortal", Hobbes se dedica ao tema da "representação", discorrendo sobre as várias formas possíveis de relações entre representados e representantes. Estes - representados e representantes - podem assumir, dependendo da relação que estabelecem, a posição de "autores" - os que detém a "autoridade", o "direito de fazer qualquer ação" - ou de "atores" - aqueles que representam ("tanto no palco quanto na conversação corrente") os autores, que agem em nome dos autores, que agem autorizados pela autoridade dos autores ${ }^{37}$. Assim, no pacto que institui o Estado, os indivíduos, como autores, autorizam - transferem sua autoridade a - "um homem" ou "uma assembleia de homens" a quem caberá, daí para frente, representá-los. O poder soberano é investido com a autoridade de representar os indivíduos e, por isso mesmo, os indivíduos são os verdadeiros autores das ações do soberano, sejam elas quais forem, pois o poder soberano nada mais é do que um representante autorizado por uma multidão de indivíduos a agir em seu nome. Para firmar o pacto que institui o Estado, os indivíduos devem

conferir toda sua força e poder a um homem, ou a uma assembleia de homens, que possa reduzir suas diversas vontades, por pluralidade de votos, a uma só vontade. O que equivale a dizer: designar um homem ou uma assembleia de homens como representante de suas pessoas, considerando-se e reconhecendo-se cada um como autor de todos os atos que aquele que representa sua pessoa praticar ou levar a praticar, em tudo o que disser respeito à paz e segurança comuns; todos submetendo assim suas vontades à vontade do representante, e

\footnotetext{
35 Ibidem, 9.47

${ }^{36}$ Ibidem, pp. 51-52

${ }^{37}$ HOBBES, Thomas. Leviata. São Paulo: Abril Cultural, 1983, p. 58
} 
suas decisões a sua decisão. Isto é mais do que consentimento, oui concórdia, é uma verdadeira unidade de todos eles, numa só e mesma pessoa, realizada por um pacto de cada homem com todos os homens, de um modo que é como se cada homem dissesse a cada homem: Cedo e transfiro meu direito de governar-me a mim mesmo a este homem, ou a esta assembleia de homens, com a condição de transferires a ele teu direito, autorizando de maneira semelhante todas as suas açōes. Feito isto, à muiltîdão assim uinida numa só pessoa se chama Estado, em latim civitas. É esta a geração daquele grande Leviatã, ou antes (para falar em termos mais reverentes) daquele Deus Mortal, ao qual devemos, abaixo do Deus Imortal, nossa paz e defesa. Pois graças a esta autoridade que the é dada por cada indivíduo no Estado, é-lhe conferido o uso de tamanho poder e força que o terror assim inspirado o torna capaz de conformar as vontades de todos eles, no sentido da paz em seu próprio país, e pela ajuda mútua contra os inimigos estrangeiros. É nele que consiste a essência do $\mathbb{E} s t a d o$, a qual pode ser assim definida: Uma pessoa de cujos atos uma grande multidão, mediante pactos recíprocos uns com os outros, foi instituída por cada um como autora, de modo a ela poder usar a força e os recuirsos de todos, da maneira que considerar conveniente, para assegurar a paz e a defesa comum. Àquele que é portador dessa pessoa se chama soberano, e dele se diz que possuil poder soberano. Todos os restantes são súditos. ${ }^{38}$

Os indivíduos se fazem representar por "um homem" ou "uma assembleia de homens" que, por sua vez, como "portadores" da "pessoa" estatal, representam o "poder absoluto". Mas esse suposto "poder absoluto" é "mortal", pois pode ser desautorizado "se for incapaz de realizar a missão para a qual foi instituído, que é a de garantir a segurança dos seus súditos e suas liberdades privadas, tais como foram definidas pelas leis civis" ${ }^{\text {m39. }}$. O poder chamado "soberano" é então, de certa forma, relativo à missão que lhe foi confiada pelos seus súditos.

Locke "apresentou a fórmula liberal do Estado moderno, potência soberana e legisladora e unidade de uma multiplicidade de 'súditos francos', assim como Hobbes quarenta anos antes - apresentara sua fórmula autoritária"40. Para Locke o "estado de natureza" não configura uma guerra generalizada. No estado de natureza, os indivíduos são livres e iguais e podem dispor livremente da sua capacidade de trabalho para transformar os recursos comuns - que a natureza espontaneamente oferece a todos - em propriedades privadas. Mas, sendo todos iguais e livres, ocorre constantemente que uns avancem sobre as propriedades - a vida, a liberdade e os bens - dos outros, gerando uma situação constante de insegurança. Além do mais, as punições, nesses casos de violação do direito natural fundamental à propriedade, fica a cargo de cada indivíduo e tende a ser parcial, interessada e não raramente desmedida. O Estado é instituído através de um pacto que visa, pela fundação de um poder imparcial de coerção e punição, garantir aos indivíduos um gozo seguro de suas propriedades.

Se o homem é tão livre no estado de natureza como se tem dito, se ele é o senhor absoluto de sua própria pessoa e de seus bens, igual aos maiores e súdito de ninguém, por que renunciaria à sua liberdade, a este império, para sujeitar-se à dominação e ao controle de qualquer outro poder? A resposta é evidente: ainda que no estado de natureza ele tenha tantos direitos, o gozo deles é muito precário e constantemente exposto às invasões de outros. Todos são tão reis quanto ele, todos são iguais, mas a maior parte não respeita estritamente, nem a igualdade nem a justiça, o que torna o gozo da propriedade que ele possui neste estado muito perigoso e muito inseguiro. Isso faz com que ele deseje abandonar esta condição, que, embora livre, está repleta de medos e perigos contínuos; e não é sem razão que ele solicita e deseja se unir em sociedade com outros, (...) visando

\footnotetext{
${ }^{38}$ Ibidem, p. 61

${ }^{39}$ CHÂTELET, François; DUGAMEL, Olivier. Histónia das Ideias Políticas. Rio de Janeiro: Zahar, 1990, p. 53

${ }^{40}$ Ibidem, p. 60
} 
a salvaguarda mútua de suas vidas, liberdades e bens, o que designo pelo nome geral de propriedade.41

O "poder supremo" é o "poder legislativo" e aqui caímos novamente numa rede complexa de relações "suplementares": o poder supremo é o poder legislativo, o poder de fazer e instituir leis ${ }^{42}$, essas leis, por sua vez, têm a única finalidade de garantir que "o povo" goze seguramente de suas propriedades fundamentais (vida, liberdade, bens), portanto "o povo" permanece sendo o único soberano do Estado43. no entanto, esse poder legislativo é efetivamente exercido por "uma ou mais pessoas" de maneira "permanente ou intermitente" "representantes" do "povo"45; além do mais, como "nem sempre há a necessidade de serem feitas novas leis, mas é sempre necessária a aplicação das leis existentes" ${ }^{\prime \prime 6}$ e como pode ser "muito grande para a fragilidade humana a tentação de ascender ao poder, não convém que as mesmas pessoas que detêm o poder de legislar tenlham também em suas mãos o poder de executar as leis"47, é necessário instituir um poder executivo cuja ação "representa" as determinações da Lei, que por sua vez representa os anseios primordiais do povo. Entretanto, o poder executivo tem ainda uma "prerrogativa": o "poder de agir discricionariamente em vista do bem público na ausência de um dispositivo legal, e às vezes mesmo contra ele"48. Mas isso não seria investir o poder executivo de um poder que, de fato, está acima do legislativo e da vontade do povo?

Rousseau institui como soberano o conceito abstrato de "vontade geral". Os primeiros capítulos do Contrato Social se ocupam em estabelecer a distinção entre uma dominação "de fato" e um poder "de direito". A dominação de fato corresponde àquele ato fundador da sociedade civil, descrito no Discurso sobre a origem e os fundamentos da desigualdade entre os homens. "O primeiro que, tendo cercado um terreno, arriscouse a dizer: 'isso é meu', e encontrou pessoas bastante simples para acreditar nele, foi o verdadeiro fundador da sociedade civil" ${ }^{\prime 4}$. Numa dominação de fato, há submissão pela necessidade. Na instituição de um poder político de direito há um pacto no qual os humanos se engajam por sua própria vontade. Pacto que Rousseau descreve nos seguintes termos:

"Cada um de nós põe em comum sua pessoa e toda a sua autoridade, sob o suipremo comando da vontade geral, e recebemos em conjunto cada membro como parte indivisível do todo."

Logo, ao invés da pessoa particular de cada contratante, esse ato de associação produz um corpo moral e coletivo, composto de tantos membros quanto a assembleia de vozes, o qual recebe desse mesmo ato sua unidade, seu eu comum, sua vida e sua vontade. A pessoa pública, formada assim pela união de todas as outras, tomava outrora o nome de cidade, e toma hoje o de república ou corpo político, o qual é chamado por seus membros: Estado, quando é passivo; soberano, quando é ativo; autoridade, quando comparado a seus semelhantes. No que concerne aos associados, adquirem coletivamente o nome de povo, e se chamaim particularmente cidadãos, na qualidade de participantes na autoridade soberana, e vassalos, quando sujeitos às leis do Estado. ${ }^{50}$

\footnotetext{
${ }^{41}$ LOCKE, John. Segundo tratado sobre o govemo civil, Petrópolis: Vozes, 1994, § 123, p. 69

${ }^{42}$ Ibidem, § 134, p. 71

${ }^{43}$ Ibidem, § 141, p. 74

${ }^{44}$ Ibidem, § 135, p. 72

${ }^{45}$ Ibidem, $\S 141$, p. 74

${ }^{46}$ Ibidem, § 153, p. 77

${ }^{47}$ Ibidem, $\S 143$, p. 74

${ }^{48}$ Ibidem, § 160 , p. 79

${ }^{49}$ ROUSSEAU, Jean-Jacques. Discurso sobre a origem e os fundamentos da desigualdade entre os homens. Brasilia: Unb, 1989, p. 84

${ }^{50}$ ROUSSEAU, Jean-Jacques. O Contrato Social http://livros01.livrosgratis.com.br/cv00014a.pdf , (I, §6), p. 10 (Úlitimo acesso em 29105/2017 às 21:00)
} 
A vontade geral tem como único fim o "bem comum", afinal, "se não houvesse algum ponto em torno do qual todos os interesses se harmonizam, sociedade nenlhuma poderia existir" 51 . E como a soberania não pode ser outra coisa senão o "exercício da vontade geral", o soberano é "um ser coletivo" que "não pode ser representado a não ser por si mesmo" 52 . Os "deputados do povo" não são "seus representantes; são quando muito seus comissários e nada podem concluir definitivamente. São nulas todas as leis que o povo não tenha ratificado; deixam de ser leis"s3. Assim, a "vontade geral", que é a "vontade do corpo do povo" é inalienável e indivisível ${ }^{54}$. Se "o povo" se compromete com a obediência a um senhor, a soberania se dissolve e se instala uma dominação de fato. No entanto, isso não significa que "as vontades dos chefes" "não possam ser consideradas como vontades gerais, enquanto o soberano, livre para a isso se opor, não o faz. Em semelhante caso, deve-se, do silêncio universal, presumir o consentimento do povo" 55

O soberano é a "vontade geral" do "povo" que "faz a lei" ".56. Mas como "não é conveniente que quem redija as leis as execute" ${ }^{n 57}$ é necessário que haja um poder executivo - que num Estado político de direito, deve necessariamente estar submetido à soberania da vontade geral. Numa democracia plena, o soberano - "o povo" - exerceria também o poder executivo. No entanto,

Rigorosamente falando, nunca existiu verdadeira democracia nem jamais existirá. Contraria a ordem natural o grande número governar, e ser o pequeno governado. É impossível admitir esteja o povo incessantemente reunido para cuidar dos negócios públicos; e é fácil de ver que não poderia ele estabelecer comissões para isso, sem mudar a forma da administração. ${ }^{58}$

E Rousseau continua: "Se houvesse um povo de deuses, ele se governaria democraticamente. Tão perfeito governo não convém aos homens" 59 .

Portanto, haverá necessariamente uma divisão entre vontade geral e poder executivo. Rousseau faz uma defesa da "aristocracia eletiva", na qual um pequeno número de indivíduos "é escolhido através de eleição, meio pelo qual a probidade, as luzes, a experiência, e todas as demais razões preferenciais e de estima púlblica, constituem outras tantas novas garantias de que seremos sabiamente governados" afinal "a ordem mais justa e natural é a em que os mais sábios governem a multidão", desde que estejamos seguros de que "a governarão em benefício dela, e não em benefício próprio"61. Quanto à monarquia, "ao contrário das outras administrações, em que um ser coletivo representa um indivíduo, nesta aqui é um indivíduo que representa um ser coletivo"62. Notemos que a palavra escollhida é "representa" (représente). Então, ainda que Rousseau tenha negado a possibilidade de que o soberano se fizesse representar, nesta passagem fica claro que o poder executivo, de alguma maneira, "representa" a vontade geral. $\mathbb{E}$ assim como havia sido em relação à democracia, Rousseau faz duras críticas à monarquia, pois "os reis desejam ser absolutos"63 e, portanto, muito facilmente colocam sua vontade particular acima da vontade geral.

\footnotetext{
51 Ibidem, (II, § 1), p. 15

52 Ibiden, (II, § 1) p. 15

${ }^{53}$ Ibidem, (III, § 15), p. 46

${ }^{54}$ Ibidem, (II, § 1; § 2), pp. 14-16

55 Ibidem, (II, § 1), p. 15

${ }^{56}$ Ibidem, (II, § 2), p. 15

${ }^{57}$ Ibidem, (III, § 4), p. 34

${ }^{58}$ Ibidem, (III, § 4), p. 34

59 Ibidem, (III, § 4), p. 34

${ }^{60}$ Ibidem, (III, § 5), p. 35

${ }^{61}$ Ibidem, (III, § 5), p. 35

${ }^{62}$ Ibidem, (III, § 6), p. 36

${ }^{63}$ Ibidem, (III, § 6), p. 36
} 
Temos então novamente uma intrincada rede de "suplementos" e de "representantes" que, dando-se em lugar do "poder soberano", ao mesmo tempo prometem e adiam sua apresentação enquanto tal. A "vontade geral" não pode ela mesma governar e, com isso, vê-se obrigada a se fazer representar de alguma forma. E, de qualquer maneira, o que pode garantir que uma vontade que se apresenta como "geral" seja realmente geral e que o bem por ela defendido seja realmente "comum"? Expressões como "vontade geral" e "bem comum" tomam como dado um "nós" ao qual pretendem transparentemente se referir.

Por mais nobre que seja, uma igualdade que reúne todos em um "nós", por exemplo, "nós, os humanos", é sempre uma igualdade afirmada, postulada, instituída. Dito de outro modo, ela se estabelece como um ato performático, e, nesse sentido, não pode jamais ser entendida como alguma coisa que já existisse por si mesma, em sua presença disponível e comum a todos.

Eim termos desconstrucionistas, por mais nobre que possa ser este "nós" - ao qual cada indiví́duo deve ser devidamente restitứdo - ele não impede nunca a validade, a necessidade, a pertinência, e mesmo a urgência de se perguntar "nós quem?", "quem diz nós?", "de que lugar se diz nós?", "com que critérios ou pressupostos?", "com vistas a que se diz nós?"64

Um claro exemplo do caráter problemático desse "nós" ao qual a passagem anterior se refere, vem da própria França de Rousseau: no país que fez a Revolução francesa, no país que cunhou a "Declaração dos direitos do homem e do cidadão", cujo artigo primeiro diz que "os homens nascem e são livres e iguais em direitos", as mulheres só conquistaram o direito de votar em 1945. E esta observação não pretende de maneira nenhuma assumir um posicionamento contrário aos direitos humanos, mas justamente chamar a atenção para a tarefa interminável de problematização das exclusões, marginalizações, inferiorizações e violências internas e externas que todo "nós" produz e legitima ao mesmo tempo em que, assumido pacificamente como dado, acaba por escamoteá-las.

\section{Considerações finais}

Existir em meio ao pathos pulsional é habitar um mundo tão insistentemente instigante quanto irremediavelmente decepcionante. Um mundo que teima em não coincidir com nossos desejos e que não cessa de impor obstáculos às nossas mais simples requisições. $E$ mesmo quando por engenho, esforço ou acaso, atingimos nossos mais estimados objetivos, o prazer não demora a se esvair ou a se transformar em tédio ${ }^{65}$. E se nos empenhamos com toda a intensidade em conservar uma configuração circunstancial que nos parece se não agradável, mas ao menos segura, o dinamismo existencial não tarda a se impor e reconfigurar mais ou menos radicalmente nossas condições. Parece que nos foi outorgada uma existência que simplesmente não podemos controlar:

Os humanos sempre souberam que aquele que age nunca sabe completamente o que está fazendo; que sempre vem a ser "culpado" de consequências que jamais pretendeu ou previu; que, por mais desastrosas e imprevistas que sejam as consequências do seu ato, jamais poderá desfazê-lo; que o processo por ele iniciado jamais se consuma inequivocamente em um único ato ou evento, e que seu verdadeiro significado jamais se desvela ao ator, mas somente à mirada retrospectiva do historiador, que não age. ${ }^{66}$

${ }^{64}$ DUQUE-ESTRADA, Paulo Cesar. Alteridade, Violência e Justiça Trilhas da Desconstrução. In: Desconstrução e Ética. Rio de Janeiro: PUC-Rio; São Paulo: Loyola, 2004, p. 43

${ }^{65}$ É a lei do "pêndulo" schopenhaueriano, que oscila "da direita para a esquerda", do "sofrimento" para o "aborrecimento". (SCHOPENHAUER, Artur. O mundo como vontade e representação. Lisboa: Rés, s/d, § 57

${ }^{66}$ ARENDT, Hannah. A condição humana Rio de Janeiro: Forense Universitária, 2010, p. 291 
Num mundo que não cessa de expor nossa fragilidade e nos atirar em situações de abandono, não é de admirar que as fantasias pulsionais de poder absoluto ocupem o primeiro plano nos mais diversos âmbitos de nossas vidas. O poder absoluto é impossível e, no entanto, é tudo que o movimento pulsional deseja. Se nos propuséssemos a sintetizar toda a nossa inquietação desejante numa formulação única, talvez a especulação mais segura consistisse em postular a existência - e o predomínio de uma pulsão de poder absoluto. Pulsão que, tendo como único objetivo o gozo absoluto, não cessa de perseguir projeções alucinatórias de um poder absoluto de realização. O poder absoluto é impossível e, no entanto, sob a pressão pulsional, as fantasias religiosas projetam Deus em seu lugar, assim como as fantasias políticas projetam em seu lugar o "poder soberano" do Estado, do Rei, da Lei ou do povo.

Como "poder absoluto" é o que nunca houve, a metafísica da soberania se faz acompanhar por uma metafísica da representação, segundo a lógica da "suplementaridade": em lugar do poder absoluto, que nunca se apresenta enquanto tal porque é impossível, instituem-se "representantes", instâncias que re-apresentam o poder absoluto, a cada vez, como possível. Mas, os "representantes", porque são apenas representantes e não o próprio poder absoluto enquanto tal, nunca cumprem exatamente o que prometem - com isso, as teorias políticas acabam apresentando um "soberano" que tem múltiplas limitações, delegações, desvios e desvirtuações do seu poder. O representante, como suplemento de um poder absoluto que năo vem porque só existe como fantasia, ao mesmo tempo, como diria Derrida, promete e adia sua presença.

Diante da proliferação de escândalos de corrupção e de vitórias eleitorais de figuras caricatas com discursos tão autoritários quanto vazios, muito se fala em "crise da representação". No entanto, a representação sempre esteve em crise. Talvez a "representação" nomeie uma crise: a crise da separação e da distinção abissal e intransponível entre o poder absoluto desejado e o poder sempre a cadla vez relativo e multifacetado que efetivamente se põe em exercício.

A teoria política moderna ocupou-se essencialmente com a questão das formas e da legitimidade do exercício do poder soberano. Mas foi em meados do século XVI que o ainda muito jovem $\mathbb{E}$ tienne de La Boétie, em seu Discurso da servidão voluntária - cujo título é bem revelador - fez a experiência de colocar esta questão pelo avesso. Isto é, perguntando-se, afinal: por que há obediência? Por que há submissão?

Quero para já, se possível, esclarecer tão-somente o fato de tantos homens, tantas vilas, cidades e naçoes suportarem às vezes um tirano que não tem outro poder de prejudicá-los enquanto eles quiserem suportá-lo; que só lhes pode fazer mal enquanto eles preferem aguentá-lo a contrariá-lo.

Digno de espanto, se bem que vulgaríssimo, e tão doloroso quanto impressionante, é veir milhões de homens a servir, miseravelmente curvados ao peso do jugo, esmagados não por uma força muito grande, mas aparentemente dominados e encantados apenas pelo nome de um só homem cuijo poder não deveria assustá-los, visto que é um só, e cujas qualidades não deveriam prezar porque os trata desumana e cruelmente. 67

Colocando a questão dessa maneira, La Boétie traz à tona uma dimensão central das experiências políticas : por que parecemos sempre dispostos a nos deixar seduzir por figuras messiânicas com discursos salvíficos e posturas autoritárias que, apresentando-se como encarnações do poder absoluto, prometem garantir - a qualquer preço - a ordem, a segurança e a estabilidade? São abundantes os exemplos históricos que nos mostram muito claramente que todas essas figuras e suas promessas somente se sustentam cobrando um altíssimo preço: silenciamentos, exílios, encarceramentos,

${ }^{67}$ LA BOÉTIE, Etienne de. Discurso sobre a servidão voluntária E-book: L.C.C. publicações eletrônicas, 2006 http://www.miniweb.com.br/biblioteca/Artigos/servidao voluntaria.pdif , pp. 5-6 (Úlitimo acesso em: $29 / 05 / 2017)$ 
censura, torturas físicas e psíquicas, assassinatos e extermínios. Os mesmos exemplos históricos mostram ainda que, além do mais, esse altíssimo preço - que é sempre caro demais -, foi cobrado em troca de promessas impossíveis de ser cumpridas. Figuras autoritárias e suas promessas de ordem, segurança, estabilidade e, portanto, de controle, atiçam as fantasias pulsionais de poder absoluto e acabam atraindo um grande número de seguidores. Ora, "autoridade", "ordem", "segurança", "estabilidade" e "controle" absolutos não passam de fantasmagorias, fantasias impossíveis e, no entanto, por corresponderem aos nossos anseios mais íntimos, sempre tão tentadoras. La Boétie nos ajuda a pensar este aparentemente estranho, mas tão comum fenômeno, que consiste na projeção de fantasias pulsionais de poder absoluto em figuras autoritárias, gerando em torno delas um verdadeiro "encantamento" e uma disposição cega para segui-las e para assumir diante delas uma postura de submissão obediente.

A convivência humana é invariavelmente problemática e envolve muitos riscos, afinal, como sempre insiste Hannah Arendt, o que nos caracteriza é fundamentalmente a "pluralidade", já que "os humanos, e não O Humano, vivem na Terra e habitam o mundo"68. E cada ser humano é um entrecruzamento único de múltiplas e variadíssimas circunstâncias, o que faz de cada um uma singularidade irredutível. Portanto, é sempre apropriada a alegoria de Schopenhauer que compara a convivência humana à de porcosespinho que atravessam uma era glacial: precisam estar juntos para se aquecerem mutuamente, mas a excessiva proximidade faz com que se firam mutuamente com seus espinhos ${ }^{69}$. A lida com a alteridade e com a diferença envolve grandes riscos, inclusive o risco de experimentarmos abalos em nosso próprio senso de "identidade", descobrindonos, enquanto compostos e atravessados por muitos "outros", irremediavelmente diferentes do que quer que acreditemos poder chamar de "nós mesmos". No entanto, talvez o maior e mais perigoso dos riscos seja aquele de cair na tentação - e na ilusão de querer resolver todos os problemas e eliminar todos os riscos de uma vez por todas, apostando numa autoridade suprema supostamente capaz de garantir uma ordem, uma estabilidade e uma segurança inabaláveis.

Talvez exigir a supressão da fantasia em nome de uma realidade pura soe ainda demasiado ingênuo e inteiramente tradicional. No entanto, será possível ao menos cultivar e mobilizar outras fantasias? Fantasias capazes de promover e estimular a convivência entre singularidades e diferenças? Convivência que, ainda que necessariamente problemática e instável, seja de alguma forma capaz de resistir à tentação de recorrer a uma autoridade suprema, diante da qual ou através da qual todas as singularidades e diferenças sejam violentamente reduzidas à homogeneidade disforme de uma identidade pré-fabricada? Será possível cultivar e mobilizar fantasias que promovam a proliferação de possibilidades existenciais ao invés da sua drástica limitação?

\section{Referências}

ARENDT, Hannalh. A condição humana. Rio de Janeiro: Forense Universitária, 2010

ALTHUSSER, Louis. Montesquieu, a Política e a História. Lisboa: Editorial Presença, 1977.

CHÂTELET, François; DUGAMEL, Olivier. História das Ideias Políticas. Rio de Janeiro: Zahar, 1990.

DERRIDA, Jacques. Força de Lei. São Paulo: Martins Fontes, 2010. . Gramatologia. São Paulo: Perspectiva, 2004.

${ }^{68}$ ARENDT, Hannah. A Condição Humana, Rio de Janeiro: Forense Universitária, 2010, p. 8

${ }^{69}$ SCHOPENHAUER, Artur. Parerga and paralipomena New York: Oxford, 2000. v. 1, 2 PP § 396, vol. II, pp. 651,652 
DUQUE-ESTRADA, Paulo Cesar. Alteridade, Violência e Justiça: Trillhas da Desconstrução. In: Desconstrução e Ética. Rio de Janeiro: PUC-Rio; São Paulo: Loyola, 2004.

FALCON, Francisco. Iluminismo. São Paulo: Atica, 1994.

FOUCAULT, Michel. Soberania e disciplina. In: Microfísica do Poder. Rio de Janeiro: Paz e Terra, 2014.

FREUD, Sigmund, O mal-estar na civilização. Rio de Janeiro: Imago, 1974. Imago, 1975.

Formulação sobre os dois princípios do funcionamento mental. Rio de Janeiro: . O Mal-estar na civilização. Rio de Janeiro: Imago, 1974.

HOBBES, Thomas. Leviatã. São Paulo: Abril Cultural, 1983.

HOBSBAWM, Eric. A Era dos Extremos. São Paulo: Companhia das Letras, 1995.

LA BOÉTIE, Etienne de. Discurso sobre a servidão voluntária. E-book: L.C.C. publicações eletrônicas,

2006. htttp://www.miniweb.com.br/biblioteca/Artigos/servidao_voluntaria.pdf, (Último acesso em: 29/05/2017.

LOCKE, John. Segundo tratado sobre o governo civil. Petrópolis: Vozes, 1994.

MAGNO, MD. Clavis Universalis. Rio de Janeiro: Novamente, 2007.

. Economia Fundamental. Rio de Janeiro: Novamente, 2012.

, A rebelião dos anjos. Rio de Janeiro: Novamente, 2009.

- Revirão. Rio de Janeiro: Novamente, 2003, p. 408.

MONTESQUIEU. O Espírito das Leis. São Paulo: Martins Fontes, 1996.

RICOEUR, Paul. De la memoire, de l'histoire, de l'oubli. Paris: Seuil, 2000.

ROUSSEAU, Jean-Jacques. Discurso sobre a origem e os fundamentos da desigualdade entre os homens. Brasília: Unb, 1989.

_- O Contrato Social. E-book: Ed. Ridendo Castigat Mores, 2002. hittp://livros01.livrosgratis.com.br/cv00014a.pdf, (Último acesso em 29/05/2017 às 21:00).

SCHMITT, Carl. Politische Theologie. Berlim: Duncker \& Humblot, 1996.

SCHOPENHAUER, Artur. O mundo como vontade e representação. Lisboa: Rés, s/d.

. Parerga and paralipomena. New York: Oxford, 2000.

VOEGELIN, Eric. As religiões políticas. Lisboa: Vega, 2002.

Doutor em Filosofia (PUC-Rio, 2016)

Professor de Filosofia Política (UERJ)

E-mail: diogobogeaa@hotmail.com 